\title{
RANCANG BANGUN GAME 2D "FINDING TAJWID" DENGAN METODE FINITE STATE MECHINE MENGGUNAKAN SOFTWARE UNITY HUB
}

\author{
Asfilia Nova Anggraini, Juniardi Nur Fadila, Fresy Nugroho \\ Jurusan Teknik Informatika, Universitas Islam Negeri Maulana Malik Ibrahim Malang \\ Jl. Gajayana No. 50 \\ $18650040 @$ student.uin-malang.ac.id,juniardi.nuregmail.com, fresy@ti.uin-malang.ac.id
}

\begin{abstract}
It is undeniable that along with the development of gaming technology that has become a means of entertainment has also developed into a means of education. One of the forms is as a teaching material in tajwid. Tajwid that many kinds make children sometimes feel difficult in the learning process. Based on the above problems, the author uses technology to construct schooling content that can boost children's learning enthusiasm, namely 2D games. 2D games are designed as attractively as possible by using Unity Hub software that utilizes the Finite State Mechine method. The purpose of making this 2D game is to increase children's learning interest in getting to know tajwid and help to remember what hijaiyah letters are contained in each law.
\end{abstract}

Keywords - 2D Games, Unity Hub, Tajwid, Finite State Mechine.

Abstrak - Tidak dapat dipungkiri seiring perkembangan teknologi game yang telah menjadi sarana hiburan turut berkembang menjadi sarana pendidikan. Salah satu bentuknya adalah sebagai bahan ajar dalam tajwid. Tajwid yang banyak macamnya membuat anak-anak kadang merasa kesulitan dalam proses belajar. Penelitian ini bertujuan untuk merancang sebuah game yang digunakan untuk membantu dalam proses pembelajaran ilmu tajwid dengan menggunakan metode Finite State Mechine. Finite State Mechine merupakan metode yang mengimplementasikan keadaan, kejadian dan aksi yang akan lebih menarik dalam proses pembelajaran dengan bermain. Sehingga hasilnya adalah anak-anak akan lebih mudah untuk mengenal dan mempelajari hukum tajwid yang ada dalam Al-Quran. Kesimpulan yang dapat diambil dari rancang bangun game ini adalah anak-anak dapat belajar dimana saja dan kapan saja ilmu tajwid dengan metode ang lebih menarik dan mudah untuk dihafalkan.

Kata Kunci - Game 2D, Unity Hub, Tajwid, Finite State Mechine.

\section{PENDAHULUAN}

Al-Quran sebagai pedoman wajib bagi setiap muslim untuk mempelajarinya dan mengamalkannya. Al-quran tidak dibaca seperti membaca teks bahasa arab, tetapi terdapat kaidah-kaidah yang harus diperhatikan karena al-quran mengandung makna yang tersirat didalamnya.

Hukum tajwid adalah ilmu mengajarkan aturanaturan membaca al-quran yang sesuai dengan kaidah. Selain itu, hukum tajwid juga mengajarkan tentang bagaimana memperindah, dan mempertajam bacaan alquran, lebih teratur dan jelas[1].

Permasalahan yang kerap kali ditemu saat ini adalah proses pembelajaran yang dinilai klasik dan sulit, sehingga perlu adanya pembaharuan di tengah perkembangan teknologi. Inovasi dan kreatifitas harus selalu dikembangkan untuk dapat survive dalam berbagai bidang. Anak-anak harusnya dapat diajarkan mulai sejak dini kerana sedang dalam proses pertumbuhan dan pembentukan watak.

Proses pembelajaaran agama salah satunya. Seiring perkembangan zaman yang dulu metode pembelajaran dengan buku saat ini tidak sedikit yang telah mengembangkan proses pembelajaran dengan memanfaatkan teknologi sebagai media pembelajaran ilmu agama[2], serta untuk mengubah paradigma seseorang akan pembelajaran agama yang sulit dan klasik[3]. Anak-anak saat ini lebih mudah menerima pembelajarannya dengan metode audio dan visual[4].

Berdasarkan penelitian sebelumnya, yang dilakukan oleh Nurul Rodotul dengan judul "Pengembangan Aplikasi Game Edukasi Mengaji dengan Metode Belajar Albarqi Dasar pada Yayasan Marhamatul Ridho berbasis Android" dimana dalam penelitian ini menghasilkan sebuah aplikasi yang menjawab masalah yang diangkat, orang tua dan guru tidak bisa menyesuaikan proses pembelajaran penalaran seorang anak dengan begitu dibuatlah aplikasi yang dapat mempermudah dalam mempelajari dan menghafalkan huruf hijriah dan 10 nama malaikat[5].

Teknologi yang dapat diterapkan sebagai media pembelajaran adalah game. Game atau permainan merupakan suatu kegiatan yang umumnya untuk mencari kesenangan atau hiburan dengan suatu peraturan untuk memainkannya yang menghasilkan kemenangan atau kegagalan[6]. Tom Watson berpendapat bahwa "anak-anak akan mendapatkan pelajaran berharga dari video game ketimbang menonton televise. Dengan bermain video game, anakanak dapat belajar melatih pikiran, konsentrasi, menjawab tantangan, dan beradaptasi terhadap perubahan di sekitar mereka"[7] 
Game edukasi merupakan jenis game yang memberikan pembelajaran kepada penggunanya melalui media permainan dalam game yang mudah untuk dipahami dan dimengerti. Game edukasi hukum tajwid merupakan game yang dibuat dengan tujuan untuk memberikan pembelajaran mengenai hukum tajwid yang diimplementasikan di dalam game. Sehingga player akan secara tidak langsung belajar tentang hukum tajwid dan diharapkan mampu untuk mengamalkan dan menerapkannya untuk menghindari kesalahan dalam membaca dan perubahan makna ayatayat al-quran.

Pembuatan game 2D "Finding Tajwid" menggunakan software Unity Hub dan bahasa pemrograman C\#(Sharp) dengan adanya game ini diharapkan dapat memberikan warna baru dalam model pembelajaran al-quran dan memberikan pendidikan kemudahan serta hiburan yang efisien, menarik, efektif, interaktif dan berdaya guna.

\section{A. Game}

Game merupakan kegiatan yang biasanya bertujuan sebagai media hiburan. Namun, seiring berkembanganya zaman game saat ini juga dikembangkan sebagai media pembelajaran. Pada saat seseorang itu memainkan game, maka orang tersebut akan mengambil peranan dalam permainan menjalankan permainan, mengambil keputusan dan mengalami akibat dari pengambilan keputusan tersebut [3].

Game dengan konten pendidikan disebut dengan game edukasi. Game edukasi bertujuan untuk memberikan pembelajaran yang secara tidak langsung akan diterima oleh pemain, sehingga ketika anak dalam kondisi perasaan senang anak akan mudah untuk menerima dan memahami materi yang disajikan.

Berdasarkan sejumlah penelitian sebelumnya memang menemukan dampak negatif dari bermain game. Penelitian itu berdasarkan hipotesa yang menyatakan bahwa media elektronik membawa pengaruh dalam kegiatan belajar dan social anak atau orang tersebut seperti membaca, berkumpul dengan keluarga atau orang sekitar. [3].

Untuk itu dibuatlah game edukasi yang didalamnya terselib sedikit materi pembelajaran sehingga setidaknya terdapat materi atau ilmu yang didapatkan oleh pemain game.

\section{B. Unity $\mathrm{Hub}$}

Unity Hub merupakan software yang digunakan untuk membuat game. Pada tahun 2009, produk telah diluncurkan secara gratis oleh Unity, sehingga terjadi peningkatan secara drastis jumlah developer yang mendaftar. Pada april 2012, unity adalah aplikasi game development yang paling banyak digunakan hingga menembus angka lebih dari 1 juta. [8]. Windows, Web, Android, Mac, iOS merupakan jenis-jenis platform fitur pengembang yang disediakan oleh Unity. Selain itu, Unity menyediakan pengembangan game 2D dan 3D. JavaScript, C\# dan BooScript merupakan bahasa pemrograan yang dapat digunakan.

\section{Tajwid}

Tajwid menurut bahasa berarti indah dan elok, atau menawan dan sempurna. Ilmu tajwid merupakan keahlian yang mengajarkan membaca al-quran berdasarkan kaidah-kaidah mulai dari huruf hingga hukum bacaannya.

Adapun perihal yang dikaji dalam penguasaan tajwid antara lain tempat keluar-masuk konsonan, hubungan antar karakter, cara pengucapan tulisan, memulai dan menghentikan bacaan, panjang dan pendeknya huruf, mengawali dan penghujung bacaan serta seni membaca sesuai al-Utsmani[3]

Hukum mempelajari tajwid menurut Para ulama adalah fardhu kifayah tetapi untuk pengamalannya adalah wajib bagi setiap muslim dalam membaca dan melafazkan al-quran (fardhu ain) sehingga setiap ayatayat dapat dibaca dan didengar dengan indah dan sempurna.

\section{Kecerdasan Buatan}

Kecerdasan buatan (AI) merupakan kecerdasan yang terdapat pada suatu sistem untuk menerjemahkan data atau inputan dari luar sistem lalu diproses dan menghasilkan suatu tindakan dari sistem berdasarkan inputan

Kecerdasan merupakan kemampuan sistem dalam menerjemahkan data untuk dapat dimengerti, dipahami dan ditanggapi dengan cepat dan baik atas menggunakan berbagai metode kecerdasan buatan serta menyelesaikan dengan efektif[9].

\section{E. Finite State Machine}

Finite state machine (FSM) sebagai kendali sistem yang dirancang dengan menerapkan tiga hal berikut: keadaan, kejadian dan aksi[9]. Sistem ini akan memproses setiap kejadian di eksternal atau dalam sistem, sehingga dapat menuju ke keadaan yang lain.

\section{METODE PENELITIAN}

Model siklus hidup pengembangan multimedia (Multimedia Development Life Cycle = MDLC) digunakan sebagai pengembangan media pembelajaran yang lebih menarik. Multimedia Development Life Cycle yang di usulkan Luther kemudian ditransformasi Sutopo meliputi enam fase yaitu sketsa, reka bentuk, penghimpunan substansi, penyatuan, uji coba dan distribusi[10]. Keenam tahap ini memang dalam implementasinya boleh tidak berurutan. Namun untuk tahap konsep menjadi yang pertama untuk dilakukan. 


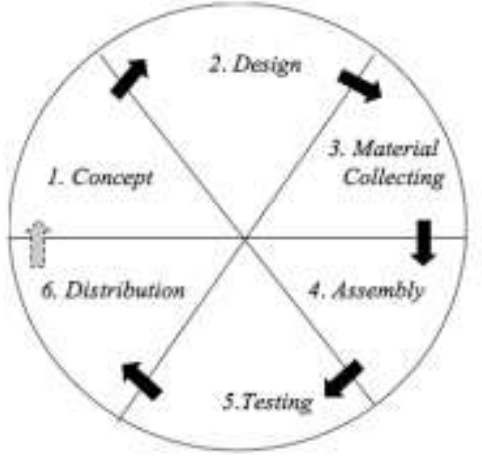

Gambar 1. Siklus Hidup Pengembangan Multimedia

1. Sketsa

Sketsa merupakan ide yang ingin dituangkan dalam suatu projek yang memiliki tujuan dan manfaat pada pengguna.

2. Reka bentuk

Reka bentuk merupakan bentuk dari implementasi konsep yang diubah menjadi suatu gambaran bentuk, model dan tampilan aplikasi yang akan dibuat.

3. Penghimpunan Substansi

Penghimpunan substansi kebutuhan alat merupakan tahapan untuk menentukan peralatan apa saja yang dibutuhkan sebagai pendukung pembuatan game.

4. Penyatuan

Proses pembuatan game dengan menggabungkan seluruh tahapan sebelumnya, sehingga game dapat dibuat sesuai dengan kebutuhan dan keinginan.

5. Uji coba

Tahap uji coba aplikasi dengan cara menilai apakah aplikasi telah sesuai dan tidak ada kesalahan.

6. Distribusi

Tahap terakhir yang dilakukan untuk publikasi sehingga aplikasi dapat dimanfaatkan oleh para pengguna.

\section{HASIL DAN PEMBAHASAN}

Penelitan ini adalah jenis penelitian yang yang dibuat untuk merancang sebuah game edukasi pembelajaran tajwid dengan software Unity Hub berbasis PC yang digunakan sebagai sarana mengenalkan ilmu tajwid.

A. Konsep

Konsep game ini secara garis besar:

1. Game ini membahasa tentang pengenalan dalam pengetahuan tajwid misalkan kaidah nun sukun bertemu tanwin, patokan mim, prinsip gunnah, asas ra'.

2. Game edukasi ini bergenre petualangan. Game dimainkan dengan satu player.
3. Terdapat skor yang dapat diperoleh user dengan cara mengambil gelembunggelembung di setiap perjalanan petualangan. Dengan setiap skor gelembung 10 poin.

Tabel 1. Semesta Pembicaraan

\begin{tabular}{|c|c|}
\hline Konsep & Keterangan \\
\hline Judul & $\begin{array}{r}\text { Game edukasi tentang ilmu tajwid } \\
\text { "FINDING TAJWID" }\end{array}$ \\
\hline Genre & Petualangan \\
\hline Pengguna & Seorang Muslim \\
\hline Audio & Instrumen Petualangan \\
\hline Interaktivitas & Pause, move, restart \\
\hline Hasil & $\begin{array}{c}\text { Memperoleh skor atau nilai apabila telah } \\
\text { menyelesaikan permainan }\end{array}$ \\
\hline
\end{tabular}

B. Desain

Aplikasi Game edukasi "FINDING TAJWID" dijalankan oleh satu atau single player sebagai pemeran game.

1. Use Case Diagram

Use Case Diagram berfungsi sebagai gambaran representasi interaksi antara sistem dengan player sehingga pengguna dapat memahami dan mengerti pengunaan system yang dibangun.

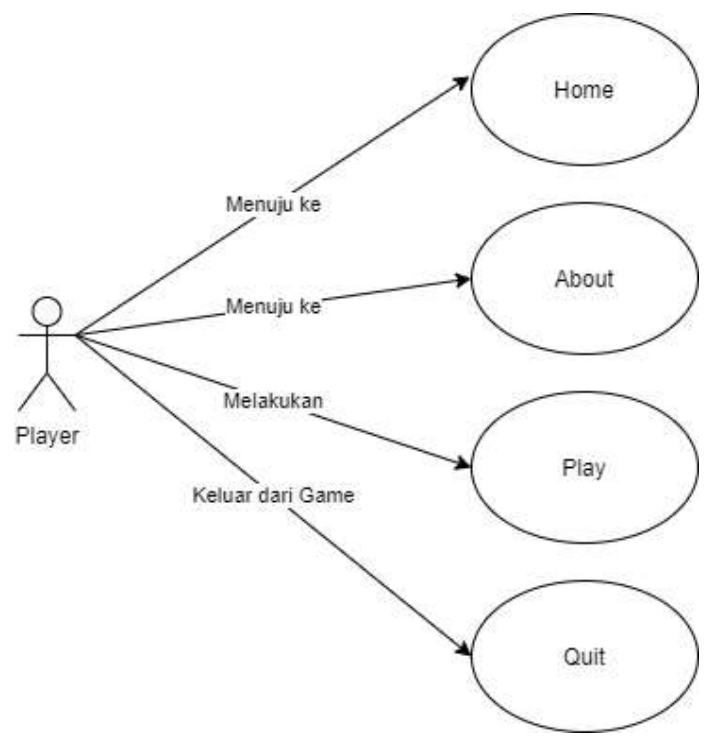

Gambar 2. Use Case Diagram

Tabel 2. Use Case

\begin{tabular}{|c|c|c|}
\hline Player & Nama & Keterangan \\
\hline Player & Home & $\begin{array}{c}\text { Use Case ini berfungsi untuk } \\
\text { halaman utama (Menu) }\end{array}$ \\
\cline { 2 - 3 } & About & $\begin{array}{c}\text { Use Case ini berfungsi untuk } \\
\text { memberikan penjelasan seputar } \\
\text { game }\end{array}$ \\
\cline { 2 - 3 } & Play & $\begin{array}{c}\text { Use Case ini berfungsi untuk } \\
\text { mulai menjalankan game dan } \\
\text { menghadapi setiap tantangan di } \\
\text { dalamnya. }\end{array}$ \\
\cline { 2 - 3 } & Keluar & $\begin{array}{c}\text { Use Case ini bertujuan untuk } \\
\text { keluar dari aplikasi game }\end{array}$ \\
\hline
\end{tabular}


2. Diagram Aktivitas

Diagram Aktivitas merupakan gambaran yang menjelaskan urutan aktifitas sistem. Berikut diagram aktivitas pada game "FINDING TAJWID”.

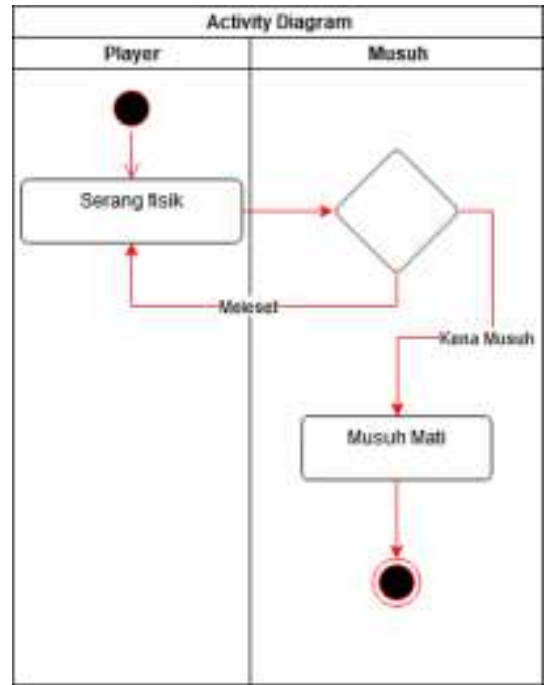

Gambar 3. Activity Diagram pemain menyerang musuh

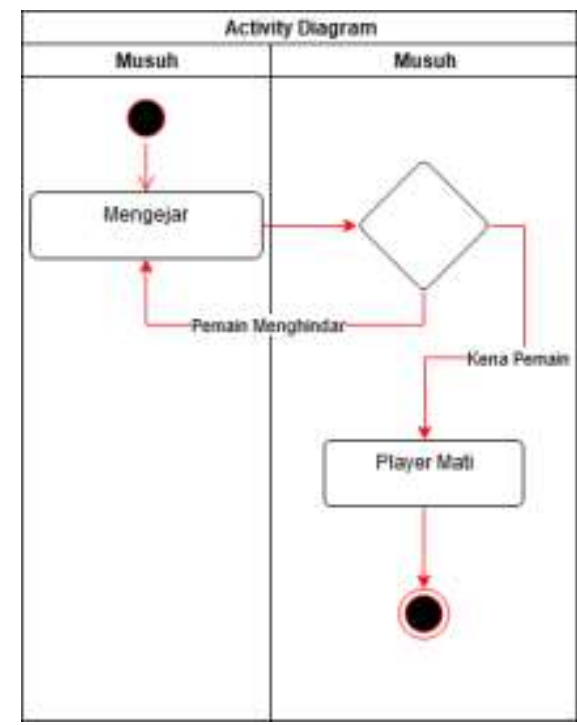

Gambar 4. Activity Diagram musuh menyerang pemain

3. $\quad$ Prose Finite State Machine (FSM)

Berikut diagram rancangan game dengan FSM

Inisialisasi input:

Gagal $\quad$ : Kembali

Dalam Finite State Machine terdapat 3 proses, yaitu keadaan, kejadian dan aksi. Apabila player sedang bermain itu termasuk dalam proses keadaan, selanjutnya apabila player terkena musuh maka itu termasuk dalam proses kejadian, dari kejadian itu maka player mendapatkan aksi dari aplikasi berupa gagal dan apabila telah menyelesaikan semua permainan pada lavel itu maka selanjutnya ke next state.

4. Tampilan Game

a. Home (Mепи)

Мепи home merupakan tampilan atau gambaran awal dari game edukasi "FINDING TAJWID”. Terdapat 3 aktivitas yaitu play, about dan keluar. Tampilan mеnи diperlihatkan dalam Gambar 5.

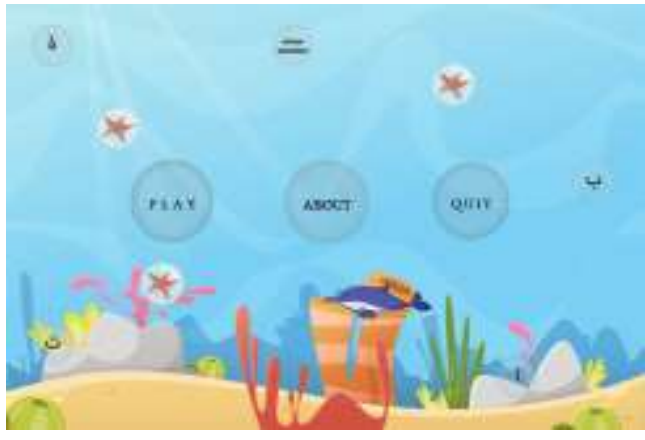

Gambar 5. Visualisasi Home

b. About

Menu ini merupakan tampilan tentang tujuan dari pembuatan game ini. sehingga player akan medapatkan gambaran nanti dalam game ini. Visualisasi about dapat dilihat dalam Gambar 6.

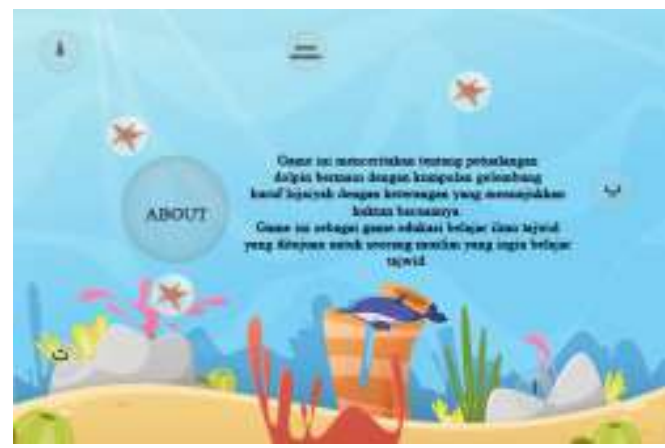

Gambar 6. Visualisasi About

c. Play

Menu play merupakan tampilan untuk mulai bermain petualangan dolpin dengan gelembung-gelembung. Visualisasi play di tunjukkan dalam Gambar 7.

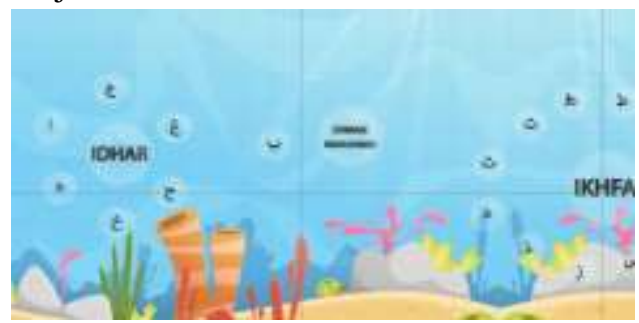

Gambar 7. Visualisasi Play 


\section{d. Avatar}

Avatar adalah karakter yang merupakan visualisasi yang dapat digerakkan secara langsung oleh player. Avatar player dipelihatkan dalam Gambar 8.

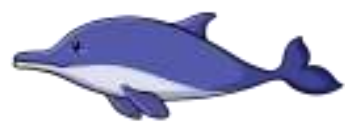

Gambar 8. Visualisasi avatar player

e. Gelembung

Gelembung merupakan skor dari permainan ini sehingga apabila player dapat mengambil gelembung lebih banyak maka skor yang didapat juga akan semakin banyak

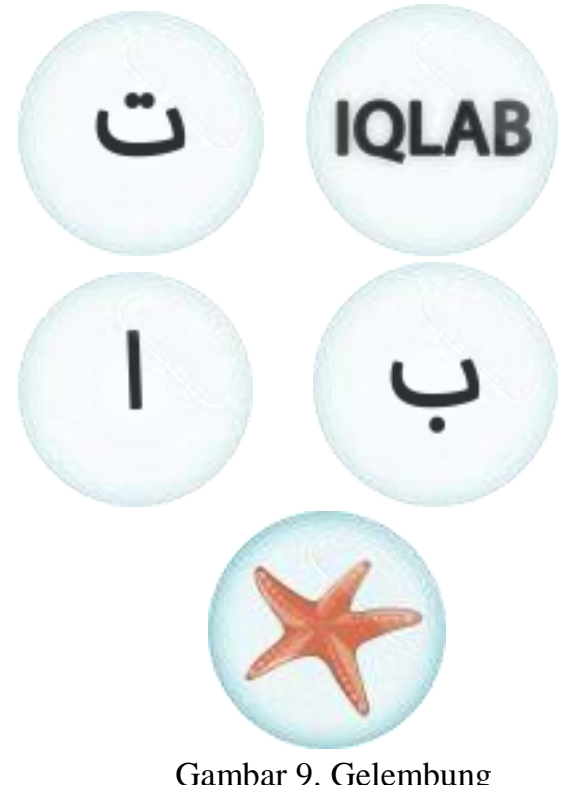

Gambar 9. Gelembung

C. Material Collecting

a. Bahasa Pemrograman : C\#

b. Game Engine : Unity

c. Sistem Operasi : Windows 10

d. Spesifikasi Laptop :

- Processor : Intel Core i3

- RAM :8 GB

- HDD : 500GB

D. Testing

Pengujian aplikasi game edukasi "FINDING TAJWID" dilakukan dengan metode blackbox di mana pada setiap tombol yang tersedia akan diuji fungsinya untuk mengetahu apakah tombol telah berjalan sesuai dengan harapan atau belum dengan cara mengeksekusi source code. Berikut Tabel 3 merupakan hasil eksperimen blackbox.

Tabel 3. Hasil eksperimen blackbox

\begin{tabular}{|c|c|c|c|}
\hline Nama & Aktivitas & $\begin{array}{c}\text { Harapan } \\
\text { hasil }\end{array}$ & $\begin{array}{c}\text { Eksperi } \\
\text { men }\end{array}$ \\
\hline
\end{tabular}

\begin{tabular}{|l|l|l|l|}
\hline $\begin{array}{l}\text { Menu } \\
\text { Main }\end{array}$ & $\begin{array}{l}\text { Membuka } \\
\text { aplikasi }\end{array}$ & $\begin{array}{l}\text { Masuk ke } \\
\text { halaman } \\
\text { menu } \\
\text { (home) }\end{array}$ & Berhasil \\
\hline $\begin{array}{l}\text { Menu } \\
\text { Play }\end{array}$ & $\begin{array}{l}\text { Menyentuh } \\
\text { tombol } \\
\text { play }\end{array}$ & $\begin{array}{l}\text { Masuk ke } \\
\text { halaman } \\
\text { permainan }\end{array}$ & Berhasil \\
\hline $\begin{array}{l}\text { Menu } \\
\text { About }\end{array}$ & $\begin{array}{l}\text { Menyentuh } \\
\text { tombol } \\
\text { About }\end{array}$ & $\begin{array}{l}\text { Masuk ke } \\
\text { halaman } \\
\text { About }\end{array}$ & Berhasil \\
\hline $\begin{array}{l}\text { Menu } \\
\text { Quit }\end{array}$ & $\begin{array}{l}\text { Menyentuh } \\
\text { tombol } \\
\text { quit }\end{array}$ & $\begin{array}{l}\text { Keluar dari } \\
\text { aplikasi }\end{array}$ & Berhasil \\
\hline Player & $\begin{array}{l}\text { Mengklik } \\
\text { tombol } \\
\text { anak panah } \\
\text { pada } \\
\text { keyboard }\end{array}$ & $\begin{array}{l}\text { Dapat } \\
\text { menggerak } \\
\text { kan player } \\
\text { ke kanan, } \\
\text { kiri, atas } \\
\text { dan bawah. }\end{array}$ & \\
\hline
\end{tabular}

\section{KESIMPULAN}

Berdasarkan reka bentuk, penerapan dan eksperimen, maka diperoleh konklusi antara lain :

1. Hal yang utama dalam pembuatan game adalah perencanaan dalam membangun game, diperlukan beberapa tahapan berdasarkan siklus hidup pengembangan multimedia. Meliputi fase sketsa, reka bentuk, penghimpunan substansi, penyatuan, uji coba dan distribusi.

2. Berdasarkan uji coba game yang telah dilakukan oleh user maka game berfungsi secara baik dan pemeliharaan diperlukan untuk membantu dalam pengembangan game kedepannya.

3. Game ini dapat dijalankan pada perangakat Laptop dan PC. Game ini menjadi game edukasi yang dapat menjadi media pembelajaran ilmu tajwid.

\section{DAFTAR PUSTAKA}

M. Z. Abidin and T. Listyorini, "Game Edukatif Membaca Al-Qur'an (Ilmu Tajwid) Berbasis Android," SINTECH (Science Inf. Technol. J., vol. 1, no. 1, pp. 1-6, 2018, doi: 10.31598/sintechjournal.v1i1.153. Permainan Edukatif Mengaji Berbasis Multimedia Interaktif Haryanto1," J. Tek. Inform. Unis, vol. 6, no. 1, pp. 8-16, 2018.

I. Mildayanti, I. K. R. Arthana, and I. G. M. Darmawiguna, "Pengembangan Game Edukasi 'Tajwid Al Qur'an' Berbasis Android," Sekol. Tinggi Teknol. Garut, vol. 5, no. 2, pp. 1-169, 
2016.

[4] L. S. Muchlis and G. R. Septianus, "Game Edukasi Belajar Mengaji Menggunakan Metode Linear Congruent Method (LCM) Berbasis Android," J. Inform. Univ. Pamulang, vol. 5, no. 2, p. 120, 2020, doi: 10.32493/informatika.v5i2.5048.

[5] N. Siregar and T. Sutabri, "Pengembangan Aplikasi Game Edukasi Mengaji," J. Teknol. Inform. Komput., vol. 5, no. 1, pp. 45-50, 2019.

[6] L. S. Mongi, A. S. M. Lumenta, and A. M. Sambul, "Rancang Bangun Game Adventure of Unsrat Menggunakan Game Engine Unity," J. Tek. Inform., vol. 13, no. 1, pp. 1-11, 2018, doi: 10.35793/jti.13.1.2018.20191.

[7] M. Q. Khairuzzaman, "GAME TAJWID THE ADVANTURE OG MADUN DENGAN MENGGUNAKAN ALGORITMA FUZZY SUGENO SEBAGAI PENGATUR PERILAKU NPC," 2016.

[8] D. Napitupulu, "PERANCANGAN PROGRAM GAME PC HACK \&amp; SLASH BERBASIS MULTIMEDIA MENGGUNAKAN UNITY 3D," pp. 82-91, 2017, doi: 10.31227/osf.io/a9yvq.

[9] M. F. Rahadian, A. Suyatno, and S. Maharani, "Penerapan Metode Finite State Machine Pada Game 'The Relationship,", Inform. Mulawarman J. Ilm. Ilmu Komput., vol. 11, no. $1, \quad$ p. $14, \quad 2016$, doi: 10.30872/jim.v11i1.198.

[10] I. Rohmawati, "Pengembangan Game Edukasi Tentang Budaya Nusantara 'Tanara' Menggunakan Unity 3D Berbasis Android," $J$. SITECH Sist. Inf. dan Teknol., vol. 2, no. 2, pp. 173-184, 2019, doi: 10.24176/sitech.v2i2.3907. 